\title{
AgAcademy: A modal platform for scaling up e-learning in Indian Agriculture in covid times
}

V V Sumanth Kumar*, Praneetha Y, Raghupathi B and Lakshmana Murthy G

Senior Scientist*, Young Professional, Research Associate and Young Professional at ICAR-National Academy for Agricultural Research Management, Rajendranagar, Hyderabad

EMail: sumanth.naarm@gmail.com

Mobile: 9502932222

\begin{abstract}
Apart from the most challenging health crisis, COVID-19 pandemic has also adversely impacted the education systems globally as it has forced for the shutdown of all the social and educational institutions amidst call for immediate lockdown of several nations. In the wake of these prevailing critical situations in India, National Agricultural Education System as similar to the other peer higher educational institutions in the country, is at the forefront in terms of quick movement to virtual platforms facilitating e-Learning to all the students across the country. In this context, "AgAcademy", an online e-Learning platform was built using an open source cloud powered software Moodle implemented using Softaculous, specially designed to power digital learning portals. This free digital learning management system offers a potential integrated solution and enables all the Agricultural Universities within the NARES to offer online based distance learning platform from the safety of their own homes of both the instructors and the learners.
\end{abstract}

Keywords: NARES, AgAcademy, Moodle, e-Learning platform.

\section{Introduction:}

Despite the critical challenges of any given time, National Agricultural Educational System of India is always committed and seeks to facilitate uninterrupted and comprehensive learning situations for all the agricultural students across the country. In the wake of prevailing adverse situations due to sudden virus outbreak, in order to mitigate the negative impact caused on the education system, efforts are directed to develop open and flexible e-Learning platforms for uninterrupted learning by the students in a short span of time for State Agricultural Universities of India. In this context, an online platform, "AgAcademy” is built using an open-source software Moodle, that offers a blendedmodel of online (asynchronous) and offline (synchronous) teaching and learning, using LMS platforms. 
Moodle is a cloud powered, free-access and open source software particularly designed to provide a single robust and secure integrated knowledge transfer system in several institutions offering digital learning platforms. The major advantage is that; this software offers for customization to create a personalized learning environment catering to the specific needs of the institution. Also, this software system offers possibility for sharing of documented resources, pictures and videos that ensures better understanding and thus it eases both the teaching and learning processes. It makes it possible for the administrator to download the software onto personal host web server and customize as per the institutional requirements. Even the software Moodle to allows to be installed in a server less elastic cloud environment thus ensuring scalability and on-demand services on the fly. Alongside, it offers for including external collaborative tools such as chats, blogs and forums facilitating quick communication between the instructors and learners for any clarifications.

The modal platform can be accessed at http://agacademy.net/. It offers role based and easy user interface to be accessed by different set of users (administrator, instructors and students) differently. While the administrator is able to create separate modules for each specific course and assign to a designated course instructor by providing secure access to the module. The course instructor can plan the own content delivery strategy by utilizing various limited available resources, and he can add all the registered students to access the same. Besides, there is also possibility to give timely assignments which ensures real time engagement of the learners. Students can leverage this digital learning platform to stay in touch with their prospective universities and help themselves from losing out during these challenging times. They can access resources offered by experts from multiple disciplines over a single platform.

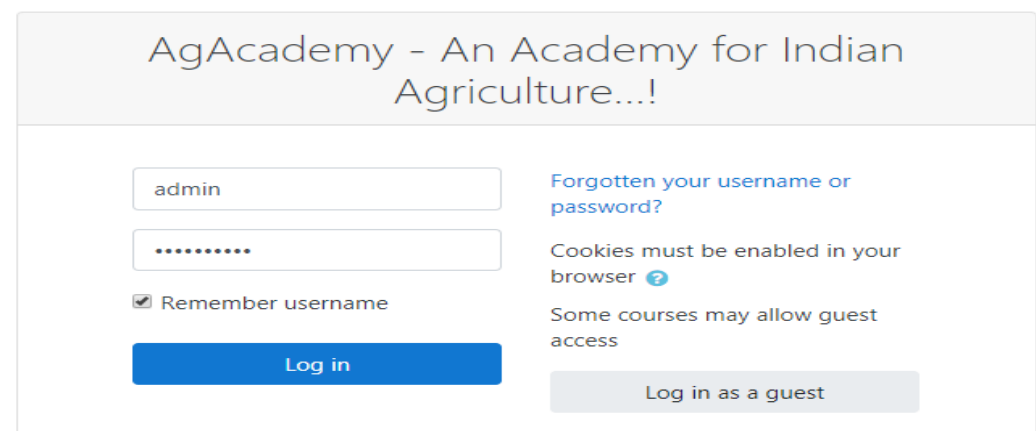

This system interface also offers to publish site blogs and important announcements that can be received from time to time through E-mail alerts or notifications that helps the students keep in pace with the updated information. 


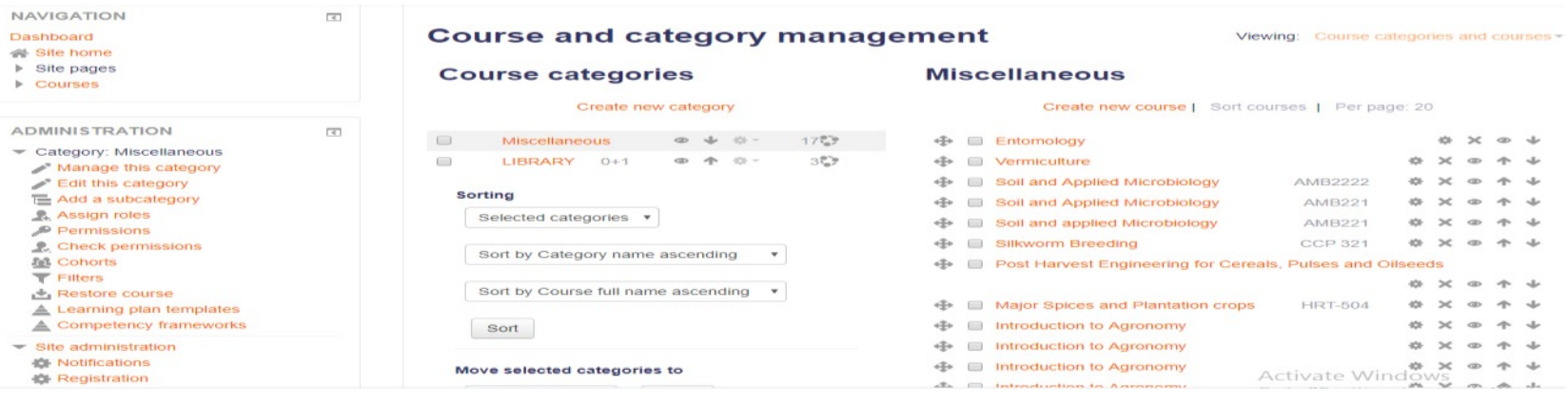

Rolling out of Moodle instances can be autmomated very easily using Softaculous Script. Softaculous is the leading Auto Installer having 454 great scripts and 1115 PHP Classes at this point of time. Softaculous is widely used in the Web Hosting industry and it has helped millions of users install applications by the click of a button. Softaculous Auto Installer easily integrates into leading Control Panels like cPanel, Plesk, DirectAdmin, InterWorx, H-Sphere ${ }^{4}$. Efforts are on to build the algorithms required for learning path construction in the platform.

Thus to meet the prevailing exigency in the society and educational system, this digital e-Learning platform developed using a free, open-source software serves as the best viable tool. An elastic cloud integrated with Moodle and Softaculous would be one of the best environment for rolling out of Moodle instances to each university, thus empowring the electronic learning in State Agricultural Universtiies. This will help all the Agricultural Universities in the country to scale up the Agricultural Education and fill in the void for regular on-campus classroom teaching, thus enhamces the effectiveness of National Agricultural Education System.

\section{References :}

1.About Moodle: Open-Source Learning Platform at https://moodle.org/

2. 'What Coronavirus Outbreak Means For Global Higher Education' at

https://www.outlookindia.com/website/story/opinion-coronavirus-outbreak-what-does-it-mean-forglobal-higher-education-in-the-time-of-covid-19/349666

3. Schools, skills, and learning: The impact of COVID-19 on education at https://voxeu.org/article/impact-covid-19-education

4. https://www.softaculous.com 